\title{
AZ ÉLETTARTAM-NÖVELŐ KÖRNYEZETBARÁT VASALÁSI ELJÁRÁS FELÜLETI MIKRO-KEMÉNYSÉGRE GYAKOROLT HATÁSÁNAK VIZSGÁLATA
}

\author{
Ferencsik Viktória \\ tanársegéd, Miskolci Egyetem, Gyártástudományi Intézet \\ 3515 Miskolc, Miskolc-Egyetemváros, e-mail: ferencsik.viktoria@uni-miskolc.hu
}

\begin{abstract}
Absztrakt
Az olyan hagyományos megmunkáló eljárások, mint az esztergálás vagy a marás alkalmazása felületi egyenetlenségek, hibák úgy, mint szerszámnyomok és karcok kialakulásához vezethetnek, mely energia disszipációt (súrlódást) és felületkárosodást (kopást) eredményez. Ezzel szemben a forgácsleválasztás nélküli környezetbarát vasalási eljárás egyértelmüen javitja a megmunkált felület integritását. Jelen tanulmány ennek az élettartam-növelö felületszilárditó eljárásnak a felületi mikro-keménységre gyakorolt hatását vizsgálja gyenge ötvözésü aluminium esetén. A kisérlet megtervezéséhez és végrehajtásához a teljes faktoriális kisérlettervezés módszere került felhasználásra.
\end{abstract}

Kulcsszavak: élettartam növelése, gyémántvasalás, Vickers keménység, felkeményedés

\begin{abstract}
Different surfaces that are machined by conventional processes such as turning and milling have inherent irregularities and defects like tool marks and scratches which cause energy dissipation (friction) and surface damage (wear). In contrast burnishing process is a kind of chip-less environment friendly technique that improves the surface integrity obviously. In this study I examine the effect of this life-enhancing surfaces strengthening method on surface micro-hardness on low alloyed aluminium components. To planning and executing the experiments I use full factorial experimental design method.
\end{abstract}

Keywords: increasing lifetime, diamond burnishing, Vickers hardness, hardening

\section{Bevezetés}

A manapság gyártott alkatrészek alapkövetelményei közt szerepel a tartósság és megbízhatóság, ezek a tulajdonságok pedig nagymértékben függnek a gyártási folyamat eredményeként kialakult felületszerkezettől [1]. A megfelelő felületi struktúra elérését széles körben kutatják többféle technológiai eljárás tekintetében is [2], pl. felületszilárdító eljárással.

A mechanikai felületszilárdítás technológiai megoldásai abban különböznek egymástól, hogy a munkadarab és a szerszám müködő felületeinek relatív elmozdulása milyen jellegü. Eszerint megkülönböztethető a gördülő relatív elmozdulásra épülő görgőzés, a dinamikus hatással alakító ütőtestes felületszilárdító technológia és a jelen tanulmány tárgyát képző, csúszó relatív elmozdulást alkalmazó vasalási eljárás. Ennek a technológiának számos elönye van: hatékonyan csökkenthető a felületi érdesség, a diszlokációk átrendezése révén növeli a felületközeli réteg mikrokeménységét, ott jelentős mértékủ nyomó maradó feszültséget képez, javítható a hengeres felületek alakhelyessége, nem igényel nagy mennyiségü hütő-kenő folyadék alkalmazást, tehát gazdaságos és kis környezetterhelésü [3-5]. 
A felületvasalás egyaránt alkalmas külső és belső hengeres felületek megmunkálására, jelen kísérletsorozat külső hengeres felület gyémántszerszámos felületvasalásával, illetve az általa okozott felületi mikro-keménység változásával foglalkozik. A kísérletek megtervezéséhez és végrehajtásához a Taguchi-féle teljes faktoriális kísérlettervet alkalmazom, mellyel empirikus képletek hatékonyan meghatározhatóak, továbbá, az eredményeket speciális viszonyszámok képzésével értékelem ki, az adott technológiai paramétertartományokon belül a legjobb eredményeket szolgáltató paraméter-beállítási értékek meghatározása céljából.

\section{Gyémántvasalás alkalmazása külső hengeres felületen}

Felületvasalás során az alakítóelem, vagyis a szerszám és a munkadarab statikus érintkezése, tehát a csúszási súrlódáskor végbemenő kölcsönhatás eredményeként következik be a képlékeny alakváltozás jellemzően 0,01-0,2 mm vastagságú felületi rétegben [6-8], ennek folyamatát szemlélteti az 1. ábra.

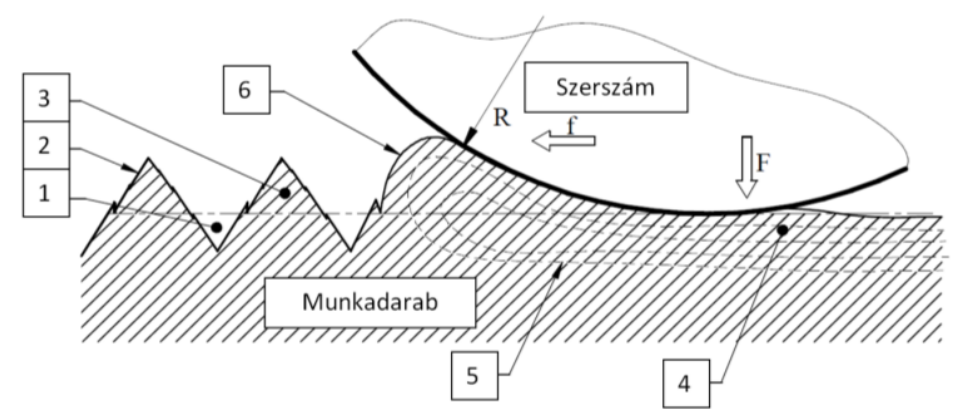

1. ábra $A$ vasalási müvelet kinematikája. [1]

1 - érdesség bemélyedése, 2 - felületi profil, 3 - érdesség kiemelkedése, 4 anyag-deformációs zóna, 5 - rugalmas és képlékeny deformációs zóna, 6 - anyaggyürödés a vasalószerszám elött

A folyamat a forgácsolás utáni felületi zónában lévő húzó maradó feszültséget nyomó maradó feszültséggé alakítja, mely által a munkadarab dinamikus terhelés alatti kifáradási viselkedése javul [9]. A felületi rétegre korlátozott hidegalakítás révén egy másik szilárdságnövelő mechanizmus is fellép, méghozzá az alakítási keményedés, mely szintén hozzájárul az élettartam növeléséhez, a továbbiakban ennek a jelenségnek a vizsgálatával foglalkozom.

\section{Anyagminőség és módszerek}

\subsection{A vizsgálat tárgya}

A megmunkálandó anyag keménysége és minősége széles tartományban változhat, ennél a kísérletnél gyengén ötvözött alumíniumot választottam (EN AW-2011), mivel az autó-, repülögép- és üripari vállalatok egyre inkább megkövetelik a nem-vasalapú anyagok alkalmazását [8], [10-12], köszönhetöen azok alacsony sürüségének és jó mechanikai tulajdonságainak.

A vasalási müveleteket, melyet $\mathrm{f}_{1}=0,2$ majd $\mathrm{f}_{2}=0,15 \mathrm{~mm}$ /ford elötolással beállított simító esztergálás előzött meg, a Gyártástudományi Intézet mühelyébe telepített OPTIMUM (OPTIturn S600) 
gyártmányú $\mathrm{CNC}$ esztergagépen végeztem el, gömbfelületü, $\mathrm{R}=3,5 \mathrm{~mm}$ méretü $\mathrm{PCD}$ (polycrystalline diamond) szerszámot alkalmazva.

\subsection{A kísérlettervezési módszer}

A kísérlet megtervezéséhez és végrehajtásához a teljes faktoriális kísérlettervezés módszerét választottuk, amely egy hatékony, aktív kísérlettervezési módszer, jelen vizsgálat szerinti modellje a 2. ábrán látható.

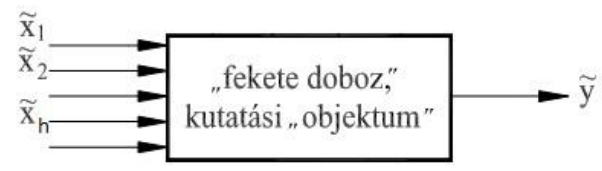

2. ábra A kisérlettervezés alapmodellje. [13]

A cél az $\tilde{y}$-mal jelölt függő változó és az $\widetilde{x_{h}}-$ mal $(\mathrm{h}=1 \ldots \mathrm{f})$ jelölt független változó közötti függvénykapcsolat meghatározása. Mindegyik független változó, vagyis faktor több értéket vehet fel, melyeket szinteknek $\left(\mathrm{p}_{\mathrm{j}}\right) ;(\mathrm{j}=1 \ldots \mathrm{m})$ nevezünk. Jelen kísérletben faktorként a vasalási járatszámot $(\mathrm{i})$, előtolást (f) és vasalóerőt (F) vizsgáltam.

\subsection{Alkalmazott vasalási paraméterek}

Az ismertetett kísérlettervezési módszernek megfelelően a kiválasztott faktorok értékeit 2 szintre állítottam be, ezt foglalja össze az 1. táblázat.

1. táblázat. Vasalási paraméterek

\begin{tabular}{|c|c|c|c|c|c|c|}
\hline \multirow{2}{*}{ Ssz. } & \multicolumn{3}{|c|}{ Vasalási paraméterek } & \multicolumn{3}{c|}{ Transzformált paraméterek } \\
\cline { 2 - 7 } & $\widetilde{x_{1}}=\mathrm{i}[\varnothing]$ & $\widetilde{x_{2}}=\mathrm{f}[\mathrm{mm} /$ ford $]$ & $\widetilde{x_{3}}=\mathrm{F}[\mathrm{N}]$ & $\mathrm{x}_{1}$ & $\mathrm{x}_{2}$ & $\mathrm{x}_{3}$ \\
\hline 1 & 1 & 0,001 & 10 & -1 & -1 & -1 \\
\hline 2 & 3 & 0,001 & 10 & +1 & -1 & -1 \\
\hline 3 & 1 & 0,005 & 10 & -1 & +1 & -1 \\
\hline 4 & 3 & 0,005 & 10 & +1 & +1 & -1 \\
\hline 5 & 1 & 0,001 & 20 & -1 & -1 & +1 \\
\hline 6 & 3 & 0,001 & 20 & +1 & -1 & +1 \\
\hline 7 & 1 & 0,005 & 20 & -1 & +1 & +1 \\
\hline 8 & 3 & 0,005 & 20 & +1 & +1 & +1 \\
\hline
\end{tabular}

A számszerü értékek meghatározása során korábbi elméleti és gyakorlati kutatómunkáim eredményeit vettem figyelembe.

\subsection{A felület mikro-keménységének mérése}

A felület mikro-keménységének mérését 3 ponton $120^{\circ}$-onként valósítottam meg Wilson Instruments Tukon 2100B Vickers keménységet mérő berendezésen. A mérés elve, mint általában minden keménységmérés esetén, annak vizsgálata, hogy egy standard erőforrást alkalmazva, hogyan áll ellen a 
kérdéses anyag a plasztikus deformációnak. A mérés során egy $136^{\circ}$-os gyémántgúlát nyomtam $1 \mathrm{~N}$ erővel 10 másodpercen keresztül a mérendő felületre, majd a berendezés saját szoftvere generálta a számszerủ eredményt.

Vizsgálataim során a keménység változásának szemléletesebbé tételéhez létrehoztam egy dimenzió nélküli viszonyszámot, melyet az alábbi képletek segítségével számítottam ki:

$$
\begin{gathered}
\rho_{H V}=\frac{H V_{\text {vasalt }}}{H V_{\text {esztergált }}} \\
\Delta \rho \%=\left(\rho_{H V}-1\right) \cdot 100 \%,
\end{gathered}
$$

ahol:

$\rho_{\mathrm{HV}} \quad$ A vizsgálat jellemző (keménység) dimenziótlan javulási viszonyszáma, jellemzi a megmunkálás hatására bekövetkező változást,

$\mathrm{HV}_{\text {vasalt }} \quad$ Vasalás utáni keménység,

$\mathrm{HV}_{\text {esztergált }}$ Esztergálás utáni keménység,

$\Delta \rho \% \quad$ A javulási viszonyszám változásának százalékos értéke

Minél nagyobb a viszonyszám értéke, annál nagyobb mértékủ javulás tapasztalható a vasalás következtében.

\section{Eredmények}

A mérési eredményeket és a számított javulási viszonyszámokat a 2. táblázatban foglaltam össze. A teljes faktoriális kísérlettervezés alkalmazásával empirikus képletet határoztam meg (3), a számítások elvégzéséhez és a szemléltetéshez (3. ábra) a MathCAD program volt felhasználva.

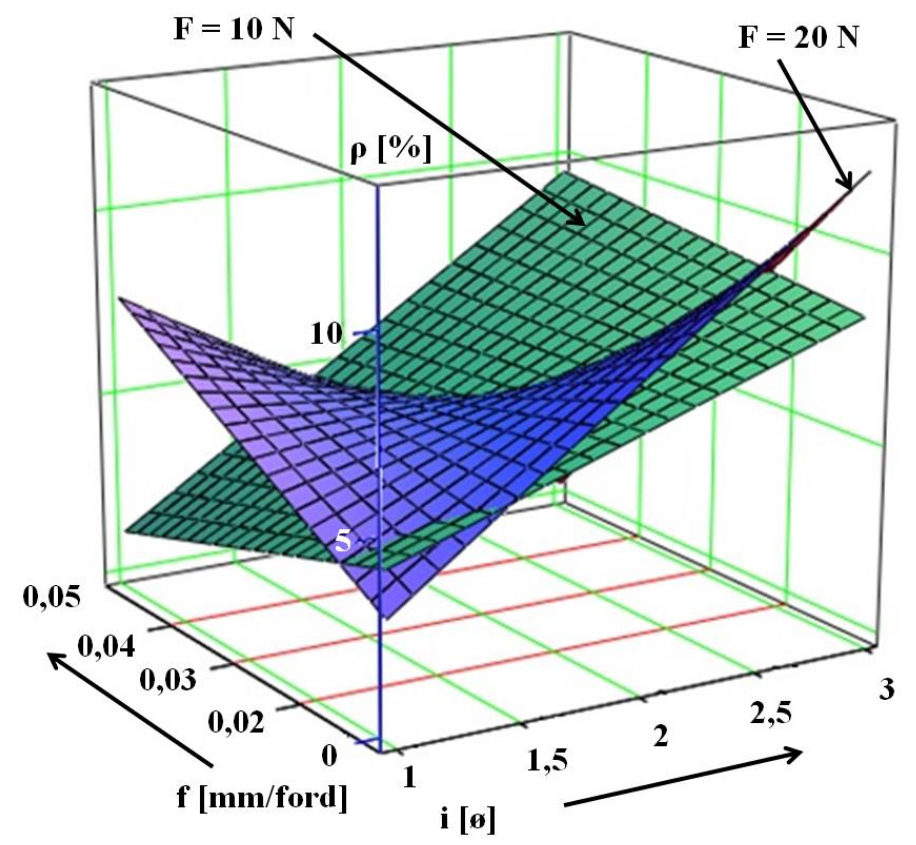

3. ábra A felületi mikro-keménység változása a vasalás hatására 
2. táblázat. Vasalási paraméterek és javulási viszonyszámok értékei

\begin{tabular}{|c|c|c|c|c|c|}
\hline & \multicolumn{2}{|c|}{ ESZTERGÁLT } & \multicolumn{2}{|c|}{ VASALT } & \multirow{2}{*}{$\rho \%$} \\
\hline Ssz. & HV & Átlag [HV] & {$[\mathrm{HV}]$} & Átlag [HV] & \\
\hline \multirow{3}{*}{1} & 174 & \multirow{3}{*}{165,67} & 175 & \multirow{3}{*}{172,33} & \multirow{3}{*}{4,02} \\
\hline & 176 & & 168 & & \\
\hline & 147 & & 174 & & \\
\hline \multirow{3}{*}{2} & 176 & \multirow{3}{*}{155,67} & 174 & \multirow{3}{*}{168,66} & \multirow{3}{*}{8,34} \\
\hline & 151 & & 148 & & \\
\hline & 140 & & 184 & & \\
\hline \multirow{3}{*}{3} & 202 & \multirow{3}{*}{168,33} & 171 & \multirow{3}{*}{170,33} & \multirow{3}{*}{1,19} \\
\hline & 153 & & 168 & & \\
\hline & 150 & & 172 & & \\
\hline \multirow{3}{*}{4} & 147 & \multirow{3}{*}{157} & 168 & \multirow{3}{*}{172} & \multirow{3}{*}{$\mathbf{9 , 5 5}$} \\
\hline & 184 & & 170 & & \\
\hline & 140 & & 178 & & \\
\hline \multirow{3}{*}{5} & 169 & \multirow{3}{*}{156,67} & 165 & \multirow{3}{*}{161} & \multirow{3}{*}{2,76} \\
\hline & 150 & & 148 & & \\
\hline & 151 & & 170 & & \\
\hline \multirow{3}{*}{6} & 141 & \multirow{3}{*}{149} & 176 & \multirow{3}{*}{167} & \multirow{3}{*}{12,08} \\
\hline & 145 & & 155 & & \\
\hline & 161 & & 170 & & \\
\hline \multirow{3}{*}{7} & 174 & \multirow{3}{*}{160,67} & 167 & \multirow{3}{*}{173} & \multirow{3}{*}{7,67} \\
\hline & 161 & & 176 & & \\
\hline & 147 & & 176 & & \\
\hline \multirow{3}{*}{8} & 188 & \multirow{3}{*}{178,33} & 197 & & \\
\hline & 165 & & 168 & 179 & $\mathbf{0 , 3 8}$ \\
\hline & 182 & & 172 & & \\
\hline
\end{tabular}

$$
\begin{aligned}
\rho_{H V}= & 11,3488-3,426 \cdot i-5,729 \cdot 10^{3} \cdot f-0,828 \cdot F+3,086 \cdot 10^{3} \cdot i \cdot f+0,508 \cdot i \cdot F+ \\
& +451,625 \cdot f \cdot F-258,125 \cdot i \cdot f \cdot F
\end{aligned}
$$

\section{5. Összegzés és következtetések}

A cikk a gyémántszerszámos felületvasalás kísérleti vizsgálatát taglalta gyengén ötvözött alumínium anyagminőség esetén. A vizsgált kísérleti paraméterek a vasalási járatszám, előtolás és erő voltak.

A kísérlet célja az volt, hogy elemezzem, ezek a paraméterek hogyan hatnak a felületi mikrokeménységre, illetve egymással milyen korrelációban állnak, melyhez felhasználtam a teljes faktoriális kísérlettervezés módszerét. Megalkottam egy dimenzió nélküli viszonyszámot $\left(\rho_{H V}\right)$, majd az empirikus képlet definiálását követően a számszerủ értékeket 3D-s diagramok formájában is bemutattam. Az elvégzett kísérlet analizált eredményei alapján az alábbi következtetéseket teszem:

- A vizsgált paramétertartományon belül a vasalási erő a 3. ábra szerint lineáris összefüggésben áll a járatszám értékével;

- A legnagyobb mértékü javulást a következő paraméterek beállítása esetén tapasztaltam: $\mathrm{i}=3, \mathrm{f}=$ $0,001 \mathrm{~mm} /$ ford, $\mathrm{F}=20 \mathrm{~N}$.

Ennek magyarázata, hogy ezzel a konfigurációval a hideg képlékenyalakítás, ezáltal a felkeményedés hatékonyabban tud megvalósulni, mivel a szerszám működő és a munkadarab megmunkálandó 
felülete nagyobb erővel és hosszabb időtartamban érintkezik. Jövőbeli kutatási elképzeléseim közt szerepel nagyobb vasalóerővel végzett kísérlet megvalósítása a többi befolyásoló paraméter változatlanul hagyása mellett.

\section{Köszönetnyilvánítás}

„Az NKFI-125117 számú projekt a Nemzeti Kutatási Fejlesztési és Innovációs Alapból biztosított támogatással, a K_17 pályázati program finanszírozásában valósult meg."”

\section{Irodalom}

[1] Dzionk, S., Scibiorski, B., Przybylski, W.: Surface Texture Analysis of Hardened Shafts after Ceramic Ball Burnishing, Materials 2019, 12(204):1-15. https://doi.org/10.3390/ma12020204

[2] Kundrák, J., Varga, G., Deszpoth, I., Molnár, V.: Some aspects of the hard machining of bore holes, Applied Mechanics and Materials 309 (2013), pp.: 126-132. https://doi.org/10.4028/www.scientific.net/AMM.309.126

[3] Varga, G., Sovilj, B., Pasztor, I.: Experimental Analysis of Sliding Burnishing, Academic Journal of Manufacturing Engineering 2013, 11(3): 6-11.

[4] Stalin John, M., Suresh, P., Raguramand, D., Vinayagam, B. K.: Surface characteristics of low plasticity burnishing for different materials using lathe, Arabian Journal for Science and Engineering. 2014, 39:3209-3216. https://doi.org/10.1007/s13369-013-0923-4

[5] Akkurt, A.: Comparison of roller burnishing and other methods of finishing treatment of the surface of openings in parts from tool steel D3 for cold forming, Journal of Materials Engineering and Performance 2011, 20(6):960-968.

[6] Luca, L., Neagu-Ventzel, S., Marinescu, I., Effects of working parameters on surface finish in ball-burnishing of hardened steels, Precision Engineering 2005, 29:253-256. https://doi.org/10.1016/j.precisioneng.2004.02.002

[7] El-Taweel, T.A., El-Axir, M.H.: Analysis and optimization of the ball burnishing process through the Taguchi technique, The International Journal of Advanced Manufacturing Technology 2009, 41:301-310. https://doi.org/10.1007/s00170-008-1485-6

[8] Varga, G.: Effects of Technological Parameters on the Surface Texture of Burnished Surfaces, Key Engineering Materials 581: Precision Machining VII 2014, 403-408. https://doi.org/10.4028/www.scientific.net/KEM.581.403

[9] Mertinger, V., Sólyom, J., Cseh, D.: Maradó feszültség vizsgálata röntgendiffrakcióval. http://www.matsci.uni-miskolc.hu/new/files/jegyzetek/diffr/segedlet_diffr.pdf

[10] Toboła, D., Rusek, P., Czechowski, K., Miller, T., Duda, K.: New Indicators of Burnished Surface Evaluation, Reasons of Application XXII 2015, 2:263-274. https://doi.org/10.1515/mms-2015-0018

[11] Stalin John, M. R., Suresh, P., Raguraman, D., Vinayagam, B. K.: Surface characteristics of low plasticity burnishing for different materials using lathe, Arabian Journal for Science and Engineering 2014, 39:3209-3216. https://doi.org/10.1007/s13369-013-0923-4

[12] Varga, G., Kundrák, J.: Effects of Technological Parameters on Surface Characteristics in Face Milling, Solid State Phenomena 2017, 261(1):285-292.

https://doi.org/10.4028/www.scientific.net/SSP.261.285

[13] Fridrik, L.: Válogatott fejezetek a gépgyártástechnológiai kísérletek tervezése témaköréből, 1989, p.109. 